\section{An Evaluation of an Interseeded Sideoats Grama Stand Four Years After Establishment ${ }^{1}$}

\section{E. EARL WILLARD ${ }^{2}$ AND JOSEPH L. SCHUSTER}

Research Assistant and Chairman, Department of Range and Wildlife Management, Texas Tech University, Lubbock.

\section{Highlight}

Sideoats grama can be successfully interseeded into abandoned cropland on the High Plains of Texas. The use of fertilizer and alfalfa with planting did not increase the stand, plant size, or production of sideoats grama. It is concluded that interseeding can increase total forage production but the inclusion of fertilizer and alfalfa in this particular study was an added expense that could not be justified. Livestock showed a definite preference for the forage on the interseeded areas over that on the non-seeded areas. Species utilization by cattle was found to be highest for kochia, followed by silver bluestem, sideoats grama, western wheatgrass, sand dropseed, red threeawn and tumble windmillgrass.

The purpose of this study was to evaluate an interseeded sideoats grama (Bouteloua curtipendula (Michx.) Torr.) stand four years after it had been interseeded. Specific objectives were to evaluate the change in forage yield of the area following the interseeding of sideoats grama; to determine stand, spread and basal area of sideoats grama plants established with three different cultural practices; and to determine the degree that each of the major grasses, forbs and minor grasses was utilized by livestock.

\footnotetext{
${ }^{1}$ Funds and facilities were furnished by the Texas Tech Research Center, Pantex, Texas. Manuscript received April 18, 1970; accepted for publication August 29, 1970.

${ }^{2}$ Present address, Utah State University, Logan, Utah.
}

\section{Methods and Procedures}

This study was conducted on the Texas Tech University Research Center near Amarillo, Texas. The research area was an 84-acre abandoned cropland pasture in an advanced stage of secondary succession (Fig. 1). This field was cultivated until the early 1940's when farming was discontinued. It was then grazed extensively by cattle but not reseeded. The soil is a Pullman silty clay loam. The vegetation in the seral community consisted primarily of western wheatgrass (Agropyron smithii Rydb.), silver bluestem (Andropogon saccharoides Swartz), buffalograss (Buchloe dactyloides (Nutt.) Engelm.), red threeawn (Aristida longiseta Steud.), sand dropseed (Sporobolus cryptandrus (Torr.) Gray) and tumble windmillgrass (Chloris verticillata Nutt.). Other species common to the High Plains of Texas were present in small amounts.

In 1963 a study was begun on the area to evaluate certain interseeding techniques for increasing the productivity of abandoned cropland or depleted ranges (Robertson and Box, 1969). Premier sideoats grama (Fig. 2) was seeded at the rate of three pounds of pure live seed per acre using an interseeder described by Dudley, Hudspeth, and Gantt (1969). In addition to the pure stand of sideoats grama, one treatment included a dryland legume (Nomad variety of alfalfa). A third treatment consisted of 30 pounds of nitrogen applied in the form of ammonium nitrate. A fourth area was left untreated as a control. Each of the treatments and the control was divided into two blocks in a randomized block design.

Production and utilization of the four arcas wcre cvaluated in 1967 during the fourth growing season after stand establishment. Five paired plots in each experimental unit were established by the random location of a plot and the selection of a similar plot based on species composition and production (Klingman et al., 1943). The paired plots were located within 10 to 20 feet of each other. A coin was then tossed to determine which plot could be grazed and which would be caged for exclusion of grazing. In the interseeded areas each cage was set directly over the row of sideoats grama; likewise, the plot to be grazed was marked with a stake driven nearly flush with the ground in the center of the row. Yearling heifers werc then put into 


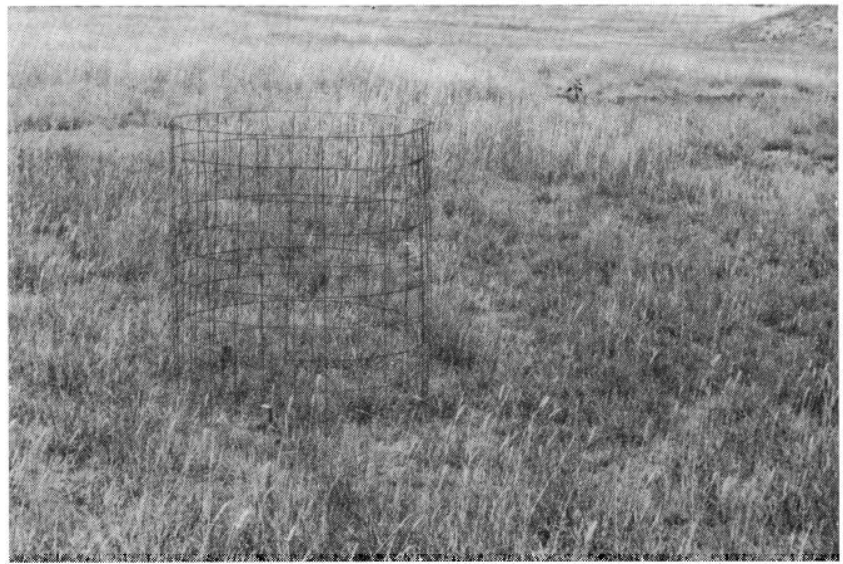

FIG. 1. An abandoned cropland pasture following approximately 25 years of natural revegetation has reached an advanced stage of secondary succession.

the pasture. The stocking rate was regulated so that approximately $50 \%$ utilization resulted.

Following the first 60 days of grazing, the total weight of herbage and that of each species was determined for each plot. Current growth was clipped from a $3.1 \mathrm{ft}$ square area within each plot and the weight was converted to pounds per acre. This information was used in the determination of production and utilization. Paired plots were then randomly relocated. These new plots were used for determination of regrowth production and utilization for an additional 60 days.

Utilization was calculated by substracting the amount of forage on each grazed plot from that of the paired plot. Total utilization consists of the sum of the utilization for the two 60-day periods.

The forage inside the exclosures at the end of the first 60-day period represents the production from the beginning of the growing season until the estimation date. When the plots were established for the second 60-day period, ocular estimates of the forage present at that time were made of the plots to be caged. Production in each caged plot for the second 60-day period was then calculated as the difference between this estimated amount present at the beginning of the second grazing period and the clipped amounts at the end of the period. The sum of the production of

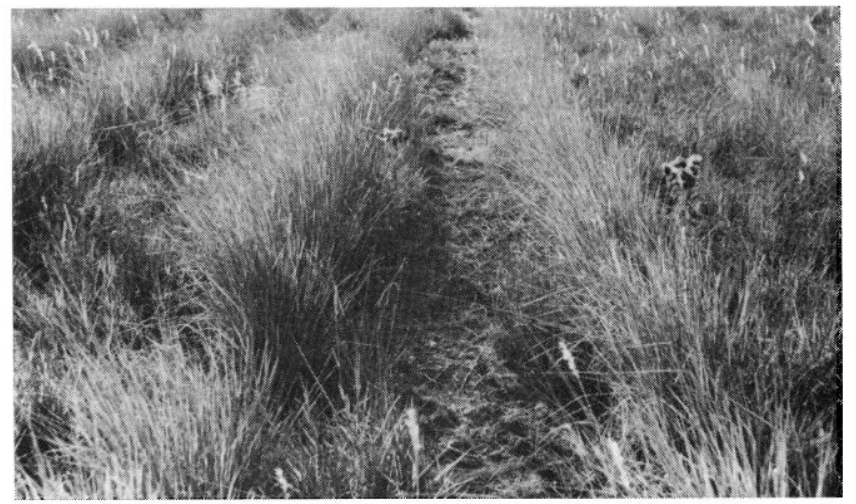

Fig. 2. Sideoats grama 4 years after having been interseeded. both periods was used as total production to the time the last estimates were made.

Forty plots were randomly established on each of the two blocks in each treated area for the determination of stand, spread toward the row middles, and basal area of sideoats grama plants. Each plot consisted of five feet of row length. Stand was determined by counting individual plants in each of the 5-foot plots. Spread toward the middle was calculated by the measurement (in inches) of the lateral spread of each plant toward row middles. Basal area was determined by direct measurement of each plant in the 5-foot plots.

An analysis of variance was used to statistically analyze the data from each measurement following procedures outlined by Snedecor and Cochran (1967). Whenever a significance for treatments was found in the $\mathrm{F}$ test of the analysis of variance, Duncan's multiple range test (LeClerg, 1966) was used to compare each treatment mean with every other treatment mean to determine where the significance lay at the .05 level.

\section{Results and Discussion}

\section{Stand and Plant Characteristics}

There was a significant reduction in stand density from 1963 to 1967 , but the stand density relationships were the same as reported by Robertson and Box (1969) for first-year establishment. Original stand density was higher in alfalfa and sideoats grama-only treatments than in the fertilizer treatment. The two treatments still maintained similar stand densities at the time of this study (Table 1).

The largest sideoats grama plants, both in average basal area and spread were found in the areas interseeded with sideoats grama-only (Table 1). Despite these differences, spread of the plants toward the row middles was minimal for all treatments.

\section{Vegetative Competition}

Sideoats grama appeared to be competing favorably with the forbs, sand dropseed, red threeawn, tumble windmillgrass and other minor

Table 1. Average stand (plants/100 ft row), spread (inches), and basal area (square inches) per plant of sideoats grama plants.

\begin{tabular}{|c|c|c|c|c|}
\hline \multirow[b]{2}{*}{ Treatment } & \multicolumn{2}{|c|}{ Stand } & \multirow{2}{*}{$\begin{array}{l}\text { Lateral } \\
\text { spread }\end{array}$} & \multirow{2}{*}{$\begin{array}{c}\text { Basal } \\
\text { area }\end{array}$} \\
\hline & $1963^{1}$ & $1967^{2}$ & & \\
\hline With alfalfa & $316.5 \mathrm{a}^{3}$ & $124.6 \mathrm{a}$ & $2.09 \mathrm{a}$ & $6.98 \mathrm{a}$ \\
\hline With fertilizer & $166.5 \mathrm{~b}$ & $92.6 b$ & $2.92 b$ & $13.55 \mathrm{~b}$ \\
\hline Alone & $342.5 \mathrm{a}$ & $111.4 \mathrm{a}$ & $3.67 \mathrm{c}$ & $18.07 \mathrm{c}$ \\
\hline
\end{tabular}

${ }^{1}$ Average of 40 samples as reported by Robertson.

${ }^{2}$ Average of 80 samples.

${ }^{3}$ Any two means of the same comparison not followed by the same letter are significantly different at the 0.05 level of significance. 


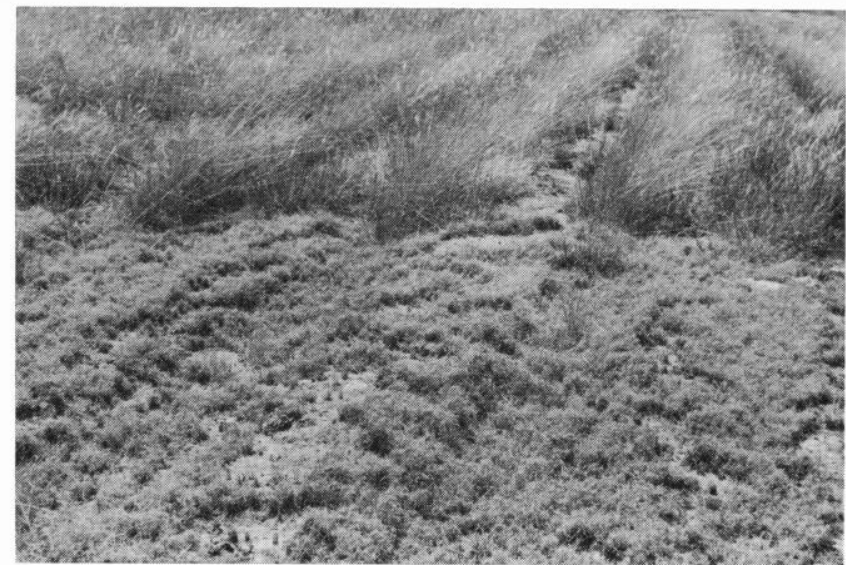

Fig. 3. Interseeded sideoats grama failed to become established in a stand of buffalograss.

grasses. These plants showed very low vigor when in competition with sideoats grama. In the more productive stands of sideoats grama, these plants showed very definite signs of mortality or reduced growth.

Western wheatgrass and silver bluestem showed fair vigor when growing in direct competition with sideoats grama. However, there was a noticeable reduction in vigor as compared to plants of the same species growing outside of the interseeded areas.

Few sideoats grama plants survived when growing in direct competition with buffalograss. There were several small dense stands of buffalograss within the interseeded plots. The number and vigor of sideoats grama plants within these stands were considerably less than in adjacent sideoats stands (Fig. 3). It is apparent that sideoats grama should not be interseeded into dense stands of buffalograss.

\section{Forage Production}

The interseeded areas produced significantly more total forage than the non-seeded control area (Table 2) but there was no significant difference in production among the interseeding treatments.

Table 2. Average herbage yield (lbs./acre, oven-dry) on unseeded and interseeded abandoned cropland.

\begin{tabular}{lccc}
\hline \hline \multicolumn{1}{c}{ Treatment } & Total & Sideoats & Other \\
\hline Sideoats grama with alfalfa & $1371 \mathrm{a}^{1}$ & $879 \mathrm{a}$ & $492 \mathrm{a}$ \\
Sideoats grama with fertilizer & $1401 \mathrm{a}$ & $1059 \mathrm{a}$ & $342 \mathrm{a}$ \\
Sideoats grama only & $1466 \mathrm{a}$ & $1012 \mathrm{a}$ & $454 \mathrm{a}$ \\
Control & $895 \mathrm{~b}$ & 0 & $895 \mathrm{~b}$ \\
\hline
\end{tabular}

${ }^{1}$ Any two means not followed by the same letter are significantly different at the .05 level of significance.
Table 3. Average utilization of total available forage and sideoats grama, expressed in weight (lbs./acre, oven-dry) and percent utilized, in different treatment areas.

\begin{tabular}{lccccc}
\hline \hline & \multicolumn{2}{c}{ Weight } & & \multicolumn{2}{c}{ Percent } \\
\cline { 2 - 3 } \cline { 5 - 6 } \multicolumn{1}{c}{ Treatment } & Total & $\begin{array}{c}\text { Sideoats } \\
\text { grama }\end{array}$ & & Total & $\begin{array}{c}\text { Sideoats } \\
\text { grama }\end{array}$ \\
\hline $\begin{array}{l}\text { Sideoats grama } \\
\text { with alfalfa }\end{array}$ & & & & & \\
$\begin{array}{l}\text { Sideoats grama } \\
\text { with fertilizer }\end{array}$ & $605.8 \mathrm{bc}^{1}$ & $366.6 \mathrm{a}$ & & 36.9 & 41.7 \\
$\begin{array}{l}\text { Sideoats grama alone } \\
\text { Control }\end{array}$ & $801.6 \mathrm{a}$ & $619.1 \mathrm{a}$ & & 54.7 & 61.2 \\
\hline
\end{tabular}

${ }^{1}$ Any two means not followed by the same letter are significantly different at the 0.05 level of significance.

No difference was found in sideoats grama production among the seeded areas. There is apparently no residual effect of the 30 pounds of nitrogen application or beneficial effect of alfalfa in the mixture. The value of alfalfa in the mixture cannot be judged conclusively, however, because only trace amounts became established. The use of alfalfa has been recommended by several researchers (Barnes et al., 1952; Dahl et al., 1967 and Hervey et al., 1960).

The species which comprised the vegetation on the non-seeded area made up approximately $1 / 3$ of the total production on the seeded areas (Table 2). These species produced only about $1 / 2$ that which they did on the non-seeded areas. Total production averaged 433 pounds more on the interseeded areas than on the non-seeded areas.

\section{Forage Utilization}

Differences in species utilization were found on the interseeded areas (Table 3). When the cattle were allowed free choice of the different areas, they grazed more pounds of forage and a larger percent of what was available in the sideoats grama-only and fertilized areas than from the nonseeded area. It is apparent that the larger amount of desirable species present in these two plots contributed to their having been grazed more. The large amount of sideoats grama on the seeded areas was a factor contributing to more use of these areas. The lower production on the non-seeded area would also account for less forage removal.

Although statistical analysis did not show significant differences in sideoats grama utilization among treatments, these differences appear real, especially for sideoats grama-only over the other treatments (Table 3). 
Table 4. Utilization (\%) of the different species growing in the research pasture.

\begin{tabular}{lc}
\hline \hline Species & Utilization \\
\hline Forbs 1 & 58.9 \\
Silver bluestem & 49.4 \\
Sideoats grama & 46.9 \\
Western wheatgrass & 45.1 \\
Sand dropseed & 38.7 \\
Red threeawn & 28.6 \\
Tumble windmillgrass & 28.0 \\
Other grasses & 16.3 \\
\hline
\end{tabular}

${ }^{i}$ Primarily kochia.

\section{Utilization of Major Species}

The degree of utilization varied considerably among the different species (Table 4). Both silver bluestem and forbs (mostly Kochia scoparia (L.) Schrad.) were utilized more heavily than sideoats grama while western wheatgrass received similar use. The other grasses were used less, indicating lower preference by the grazing animals.

The cattle showed a definite preference for kochia when they first were introduced into the pasture. As kochia started to mature in July, grazing changed to sideoats grama and sand dropseed through July and to the middle of August. Preference was shown for sideoats grama, western wheatgrass and silver bluestem during the latter part of the growing season. Use was made on red threeawn, tumble windmillgrass and other minor grasses only in the early part of the grazing season.

\section{Literature Cited}

Barnes, O. K., R. L. Lang, and A. A. Beetle. 1952. Grass establishment on Wyoming dryland. Wyo. Agr. Exp. Sta. Bull. 314. 24 p.

Dahi, B. E., A. C. Evfrson, J. J. Norris, and A. H. DenHAM. 1967. Grass-alfalfa mixtures for grazing in Eastern Colorado. Colo. Agr. Exp. Sta. Bull. 529-S. 25 p.

Dudley, R. F., E. B. Hudspeth, JR., and C. W. Gantt. 1966. The bushland range interseeder. J. Range Manage. 19:227-229.

HeRveY, D. F. 1960. Improving great plains rangelands by interseeding. Proc. 8th Int. Grassl. Congr. 8 p.

Klingman, D. L., S. R. Miles, and G. O. Mott. 1943. The case method for determining consumption and yield of pasture herbage. Amer. Soc. Agron. J. 35:739-746.

LeClerg, E. L. 1966. Mean separation by the functional analysis of variance and multiple comparisons. U.S. Dep. Agr., Agr. Res. Serv. Pub. 20-3. 33 p.

Robertson, T. R., JR. 1965. Interseeding abandoned cropland with sideoats grama grass, Bouteloua curtipendula (Michx.) Toff., on the High Plains of Texas. Unpublished M.S. Thesis. Texas Tech Univ., Lubbock, Texas. $47 \mathrm{p}$.

Robertson, T. R., JR., ANd T. W. Box. 1969. Interseeding sideoats grama on the Texas High Plains. J. Range Manage. 22:243-245.

Snedecor, G. W., and W. G. Cochran. 1967. Statistical methods. Iowa State Univ. Press, Ames, Iowa. 593 p. 